\title{
PENGEMBANGAN MODEL PEMBELAJARAN KOOPERATIF TIPE JIGSAW DENGAN PERMAINAN LET'S BE CREATIVE (LBC) PADA MATERI BANGUN RUANG SISI DATAR KELAS VIII SMP IT NUR HIDAYAH SURAKARTA
}

\author{
Isna Nur Lailatul F ${ }^{1}$, Mardiyana ${ }^{2}$, Dewi Retno Sari Saputro ${ }^{3}$ \\ ${ }^{1,2,3}$ Prodi Magister Pendidikan Matematika, FKIP Universitas Sebelas Maret Surakarta
}

\begin{abstract}
The aims of this study are: (1) to describe the process of jigsaw model with LBC game in polyhedra (cubes, cuboids, prisms and pyramids) learning materials at VIII grade of high school students. (2) to get the result of jigsaw model with LBC game are valid, practical use in learning, and effectively use in learning. The discussion in this study using a model of the development of four D Thiagarajan (4D) includes; definition phase (define), stage design (design), stage of development (develop), and the deployment phase (disseminate). The results of this developmental study are: (1) a valid model of jigsaw with LBC game which applied in polyhedra (cubes, cuboids, prisms and pyramids) learning materials of VIII grade Junior High School with an average score rate is 3,55 and include in very good criteria. (2) a practical model of jigsaw with LBC game with a practical implementative average score rate (before implementation) is 3,44 and include in very good criteria and the teacher stated that jigsaw model with LBC game can be implemented in the classroom. (3) an effective model of jigsaw with LBC game to be implemented in the classroom. The effectiveness of the model according to the creativity in solving the mathematic problem which treated with jigsaw model with LBC game is better than jigsaw model only, the assessment by the observer when the teaching and learning process using jigsaw model with LBC game is 3,1375 include in good criteria with reliability rate $87,83 \%$. Students' respond toward the model is adequate with total average rate 2,793 and include in adequate category. The teacher also gives positive statements that jigsaw model with LBC game is good, the students being active and LBC game attracts all of the students. According to the discussion result, it can be concluded that jigsaw model with $\mathrm{LBC}$ game fulfil the criteria validity, practicality, and effectivity.
\end{abstract}

Keywords: Jigsaw model development with LBC game, creativity.

\section{PENDAHULUAN}

Guilford (dalam Fasko(2000)) menyatakan "the problems of creativity in the educational setting are endless, and the scope of research in this area is rapidly spreading" akan tetapi Murniati (2012:26) menyatakan bahwa saat ini, penelitian tentang kreativitas masih sangat kurang di Indonesia akibatnya profil kreativitas manusia Indonesia dengan segala dimensinya masih banyak yang belum terungkap. Sejalan dengan hal itu, aspek kreatif mulai diperhatikan seperti yang tercantum pada UndangUndang No.20 Tahun 2003 menyatakan salah satu tujuan pendidikan nasional yakni mengembangkan potensi peserta didik agar menjadi manusia yang kreatif. Cara berpikir kreatif dapat dikembangkan melalui pendidikan matematika. Haylock (1997) mengatakan bahwa berpikir kreatif selalu melibatkan fleksibilitas. Dalam konteks matematika, kriteria kefasihan tampak kurang berguna dibandingkan dengan fleksibilitas. Haylock (1997) menjelaskan bahwa pemecahan masalah dapat menjadi pendekatan untuk mengetahui 
kemampuan berpikir kreatif siswa. Indikator berpikir kreatif dapat dilihat dari produksi divergen yang meliputi fleksibilitas, keaslian dan kelayakan. Akan tetapi menurut Siswono (2013) berpikir kreatif jarang ditekankan pada pembelajaran matematika karena strategi pembelajaran yang diterapkan cenderung berorientasi pada pengembangan pemikiran analitis dengan masalah-masalah yang rutin.

Baghetto (2010) menyatakan bahwa peneliti-peneliti telah mengidentifikasi kendala-kendala dalam pengembangan kreativitas di kelas, yaitu praktek pengajaran yang konvergen, sikap dan keyakinan guru terhadap kreativitas, motivasi lingkungan, dan keyakinan siswa sendiri terhadap kreativitas. Pengajaran konvergen cenderung didominasi guru untuk "bicara" atau lebih dari 70\% waktu pelajaran digunakan untuk mentransfer informasi. Sedangkan Simonton (dalam Muniarti, 2012:119) menyatakan bahwa,"Great thinkers tend to have great teachers". Pernyataan ini mengandung arti seorang pemikir hebat menandakan bahwa memiliki guru yang hebat.

Dalam perkembangan pendidikan di Indonesia, pandangan mengenai peran guru sebagai pusat pembelajaran berubah menjadi fasilitator dalam kegiatan belajar siswa. Berbagai model pembelajaran diterapkan dalam kelas baik oleh guru maupun para peneliti untuk memperoleh peningkatan hasil belajar. Carpenter (2006) menyatakan bahwa mengajar pada kelas yang besar seharusnya berusaha memasukkan konstruktivisme, metode pengajaran aktif pada kelas disaat apapun yang memungkinkan. Berdasarkan penelitian yang dilakukan Carpenter (2006) meneliti efektivitas dari 5 model pembelajaran (lecture,lecture/discussion combination, jigsaw, case study, team project) pada kelas besar yang telah disiapkan dan menyimpulkan bahwa skor siswa meningkat paling banyak pada kelas Jigsaw. Tetapi Perkins dan Saris (2001:111-113) menyatakan beberapa kekurangan diantaranya "The problem of bright students becoming bored" dimana penelitian menunjukkan bahwa tingkat kebosanan siswa lebih rendah daripada di kelas tradisional. Vygotsky (1962) (dalam Santrock, 2007) mengatakan bahwa permainan adalah latar yang sangat baik untuk perkembangan kognitif. Rockler (1998:105) menyatakan bahwa game atau permainan dapat menjadi sebuah strategi pembelajaran yang dapat memfasilitasi proses berpikir kreatif siswa. Kesempatan mengembangkankan diri, untuk menggali potensi diri diperlukan siswa untuk melatih berpikir kreatif. Meletiou (2012) merancang sebuah permainan yang meningkatkan suasana belajar matematika. Dengan eksperimentasi yang dilakukan diperoleh bahwa dengan variasi game yang mendidik, guru semakin familiar dengan prinsip desain permainan konstruktivisme. 
Penelitian oleh Siswono (2010) tentang melevelkan tingkat berpikir kreatif siswa kelas VIII SMP dalam pemecahan dan pengajuan masalah pada materi bangun datar diperoleh 13 siswa sebagai subjek penelitian diperoleh hasil dari ketigabelas siswa hanya 3 siswa yang memiliki tingkat berpikir kreatif yang tinggi. Ini menunjukkan bahwa tidak banyak siswa yang kreatif pada materi bangun datar. Kemampuan berpikir kreatif siswa banyak dikaji pada bidang geometri karena pada bidang geometri banyak berkaitan dengan masalah realistik. Materi Bangun Ruang Sisi datar merupakan salah satu materi yang dipelajari pada semester dua kelas VIII SMP. Materi bangun ruang sisi datar sesungguhnya telah diperkenalkan pada siswa sejak sekolah dasar, hanya saja saat sekolah dasar terbatas pada pengetahuan mengenai macam, mencari luas permukaan dan volume. Perbedaannya dengan materi bangun ruang sisi datar di SMP adalah terkait pemahaman konsep dan unsur-unsur yang lain. Karena materi bangun ruang sisi datar bukanlah materi baru bagi siswa dan siswa telah memiliki pengetahuan awal mengenai bangun ruang sisi datar maka pembelajaran haruslah menjadi pembelajaran yang bermakna dan saling berkaitan. Langkah pembelajaran model Jigsaw juga dinilai dapat diterapkan pada materi bangun ruang kelas VIII SMP.

Bertolak dari berbagai kondisi yang diuraikan tersebut, penulis tertarik mengembangkan model pembelajaran Jigsaw dengan permainan yang edukatif pada materi bangun ruang sisi datar kelas VIII SMP. Permainan edukatif dirancang untuk melatih kefasihan dan fleksibilitas siswa pada materi bangun ruang sisi datar. Selanjutnya, permainan ini dikembangkan menggunakan program macromedia fash 8 dan dinamakan Let's be Creative (LBC).

Tujuan penelitian ini untuk: (1) Mendeskripsikan proses pengembangan model Jigsaw dengan permainan LBC pada materi bangun ruang kelas VIII SMP. (2) Mendapatkan hasil pengembangan model Jigsaw dengan permainan LBC pada materi bangun ruang kelas VIII SMP yang valid, praktis dan efektif digunakan dalam pembelajaran.

\section{METODE PENELITIAN}

Jenis penelitian ini adalah penelitian pengembangan (research and development), sedangkan prosedur penelitian mengacu pada prosedur $R \& D$ yang dikemukakan oleh Thiagarajan (1974) yaitu model pengembangan four D, dengan tahapan meliputi; tahap pendefinisian (define), tahap perancangan (design), tahap pengembangan (develop), dan tahap penyebaran (disseminate). Sedangkan krietria keberhasilan model pembeajaran mengacu pada kriteria Nievenn (2000), model dikatakan berkualitas baik jika dipenuhi 
valid yakni validator menilai bahwa model Jigsaw dengan permainan LBC valid apabila hasil yang diperoleh dari analisis skor kevalidan model termasuk dalam kriteria cukup atau baik atau sangat baik. Model dikatakan praktis jika hasil yang diperoleh dari analisis skor kepraktisan model termasuk dalam kriteria cukup atau baik atau sangat baik dan guru menyatakan bahwa model dapat diterapkan di kelas. Sedangkan efektif jika dipenuhi model Jigsaw dengan permainan LBC memberikan kreativitas siswa dalam memecahkan masalah lebih baik dibanding model Jigsaw, siswa memberikan respon positif terhadap penggunaan model pembelajaran, guru memberikan respon positif penggunaan model pembelajaran, penilai menyatakan bahwa model pembelajaran efektif bagi siswa.

Subjek penelitian adalah validator modul yang menjadi sasaran uji pengembangan model/validasi ahli, peserta didik dan guru kelas uji coba yang menjadi sasaran uji coba model. Validator model terdiri dari ahli materi beserta ahli pembelajaran, ahli media. Peserta didik dan guru kelas uji coba model yang dilakukan terbatas pada satu kelas eksperimen. Pada tahap pengembangan meliputi kegiatan validasi model, menilai kepraktisan dan uji coba lapangan.

Instrumen untuk memperoleh data mengenai validitas digunakan lembar validasi model oleh ahli materi beserta ahli pembelajaran, dan ahli media dengan format penilaian empat poin dari skala Likert dengan kriteria penilaian antara lain sangat baik, baik, kurang dan sangat kurang. Aspek - aspek yang perlu divalidasi oleh ahli materi beserta ahli kurikulum dan pembelajaran mencakup aspek rasional teoritik, sintaks, prinsip reaksi, sistem sosial, sistem pendukung dampak instruksional dan dampak pengiring. Aspek yang perlu divalidasi oleh ahli media mencakup pandangan umum, isi dan tampilan permainan (game). Untuk memperoleh data kepraktisan model digunakan lembar penilaian keterlaksanaan berupa angket dengan skala likert 4 poin dengan krietria penilaian sangat kurang bisa dilakukan, kurang bisa dilakukan, bisa dilakukan, sangat bisa dilakukan. aspek - aspek yang diamati berhubungan dengan langkah - langkah pembelajaran menggunakan model pembelajaran Jigsaw dengan permainan LBC. Untuk menilai keefektifan digunakan instrumen lembar pengamatan kegiatan pembelajaran menggunakan menggunakan format penilaian empat poin dari skala Likert dengan kriteria penilaian antara lain selalu, sering, kadang - kadang, dan tidak pernah. Lembar angket respon guru berupa uraian pertanyaan yang harus diberi tanggapan atau komentar dan kesimpulan mengenai pembelajaran. Lembar angket respon siswa menggunakan format penilaian empat poin dari skala Likert dengan kriteria penilaian antara lain sangat setuju, setuju, tidak setuju, dan sangat tidak setuju. Untuk menilai kreativitas siswa dalam 
memecahkan masalah matematika digunakan tes pemecahan masalah dengan bentuk uraian.

Untuk menghitung rerata skor kevalidan, kepraktisan, kefektifan oleh observer dan respon siswa terhadap model Jigsaw dengan permainan LBC digunakan rumus sebagai berikut.

$\bar{x}=\frac{\sum_{i=1}^{n} x_{i}}{n}$

Keterangan :

$\bar{x} \quad$ : rerata skor

$x_{i} \quad$ : skor pernyataan ke- $i$

$n$ : banyaknya pernyataan

Data yang diperoleh berupa data kuantitatif kemudian diubah menjadi data kualitatif dengan pedoman pengubahan data kuantitatif menjadi kualitatif seperti pada Tabel 1 .

Tabel 1. Pedoman Pengubahan Data Kuantitatif menjadi Kualitatif

\begin{tabular}{lc}
\hline \multicolumn{1}{c}{ Rentang skor $(i)$} & Kriteria \\
\hline $\bar{x}>3,4$ & Sangat Baik \\
$2,8<\bar{x} \leq 3,4$ & Baik \\
$2,2<\bar{x} \leq 2,8$ & Cukup \\
$1,6<\bar{x} \leq 2,2$ & Kurang \\
$\bar{x} \leq 1,6$ & Sangat kurang \\
\hline
\end{tabular}

(Widoyoko, 2009:238)

Untuk menilai apakah model Jigsaw dengan permainan LBC lebih baik dalam memberikan skor kreativitas dalam memecahkan masalah matematika dilakukan menggunakan analisis variansi satu jalan dengan sel sama. Sebelum diberikan perlakuan model dilakukan uji keseimbangan terlebih dahulu. Uji keseimbangan ini bertujuan untuk mengetahui apakah kelompok eksperimen pertama, kelompok eksperimen kedua dalam keadaan seimbang atau tidak. uji keseimbangan siswa menggunakan uji beda rerata dengan taraf signifikansi 0,05. Uji normalitas populasi menggunakan metode Lilliefors, uji homogenitas variansi populasi menggunakan uji Barlett dengan metode Chi-square sebagai uji prasyarat sebelum dilakukan uji keseimbangan.

Setelah data hasil penelitian berupa hasil tes pemecahan masalah diperoleh terlebih dahulu dilakukan uji prasyarat uji hipotesis yang terdiri dari uji normalitas populasi dengan menggunakan metode Lilliefors dan uji homogenitas variansi populasi menggunakan uji Barlett dengan metode Chi-square. Kemudian dilakukan uji hipotesis menggunakan uji-t dengan taraf signifikansi 0,05 . Uji hipotesis ini bertujuan untuk mengetahui apakah model pembelajaran Jigsaw dengan permainan LBC memberikan kreativitas dalam memecahkan masalah matematika lebih baik dibanding model pembelajaran Jigsaw. 


\section{HASIL PENELITIAN DAN PEMBAHASAN}

1. Tahap Pendefinisian (Define)

a. Analisis awal - akhir

Pada analisis awal - akhir dilakukan analisis terhadap silabus mata pelajaran Matematika kelas VIII SMP/MTs Silabus pembelajaran untuk materi bangun ruang seperti pada Tabel 2 .

Tabel 2. Silabus Matematika Materi Bangun Ruang Sisi Datar

\begin{tabular}{cl}
\hline Kompetensi Dasar & Materi yang perlu dipelajari \\
\hline $\begin{array}{c}\text { 5.1 Mengidentifikasi sifat-sifat kubus, balok, } \\
\text { prisma dan limas serta bagian-bagiannya. }\end{array}$ & $\begin{array}{l}\text { Sifat-sifat dan definisi kubus, balok, } \\
\text { prisma dan }\end{array}$ \\
$\begin{array}{c}\text { 5.2 Membuat jaring-jaring kubus, balok, } \\
\text { prisma dan limas }\end{array}$ & $\begin{array}{l}\text { Jaring-jaring kubus, balok, prisma dan } \\
\text { limas }\end{array}$ \\
$\begin{array}{c}\text { 5.3 Menghitung luas permukaan dan volume } \\
\text { kubus, balok, prisma dan limas }\end{array}$ & $\begin{array}{l}\text { Rumus luas permukaan dan volume } \\
\text { kubus, balok, prisma dan limas }\end{array}$ \\
\hline
\end{tabular}

b. Analisis Siswa

Kelas VIIIA SMP IT Nur Hidayah tahun ajaran 2014/2015 merupakan kelas ujicoba pelaksanaan model pembelajaran Jigsaw dengan permainan LBC pada materi bangun ruang. Kelas VIIIA terdiri dari 30 siswa putra dengan rentang usia 13-16 tahun sesuai dengan teori Piaget bahwa siswa dalam kelas VIII A berada pada tahap operasi formal dimana anak mulai mampu melakukan penalaran dengan menggunakan hal-hal yang abstrak, sehingga pembelajaran bangun ruang tidak diperlukan adanya lagi model bangun ruang.

Salah satu kompetensi dasar yang telah dikuasai peserta didik pada saat kelas VII adalah Bangun Datar, dan pada saat kelas VIII semester satu adalah materi Pytagoras. Kompetensi dasar tersebut mendukung peserta didik saat mempelajari materi Bangun Ruang Sisi Datar.

c. Analisis Tugas

Sub keterampilan yang memadai dan diperlukan dianalisis sesuai dengan karakteristik paham konstruktivisme dan kreativitas agar tugas yang terkandung dalam LKS dan Permainan LBC memenuhi karakteristik konstruktivisme dan kreativitas. Hasil analisis tugas terangkum dalam Tabel 3.

Tabel 3. Hasil Analisis Tugas

\begin{tabular}{lrll}
\hline $\begin{array}{l}\text { Ketrampilan Utama yang } \\
\text { Diperoleh }\end{array}$ & $\begin{array}{l}\text { Sub Keterampilan yang Memadai dan } \\
\text { Diperlukan }\end{array}$ \\
\hline $\begin{array}{l}\text { Mendefinisikan } \\
\text { bangun ruang }\end{array}$ & pengertian & Melalui diskusi kelompok ahli siswa dapat \\
& & menyebutkan sifat-sifat dan unsur bangun \\
& ruang sehingga dari sifat dan unsur yang \\
& diketahui siswa dapat membatasinya menjadi \\
& sebuah konsep yang selanjutnya disusun \\
untuk menjadi sebuah pengertian atau
\end{tabular}




\begin{tabular}{|c|c|}
\hline Utama yang & $\begin{array}{l}\text { Sub Keterampilan yang Memadai dan } \\
\text { Diperlukan }\end{array}$ \\
\hline $\begin{array}{l}\text { Menyebutkan } \\
\text { bangun ruang }\end{array}$ & $\begin{array}{l}\text { definisi. Siswa mengaitkan definisi antara } \\
\text { Kubus, Balok, Prisma dan Limas. } \\
\text { Dengan menyebutkan berbagai macam } \\
\text { jaring-jaring dari sebuah bangun ruang maka } \\
\text { siswa akan mampu berpikir secara luwes. }\end{array}$ \\
\hline $\begin{array}{l}\text { Menentukan Luas Permukaan } \\
\text { dan Volume Bangun Ruang }\end{array}$ & $\begin{array}{l}\text { Melalui diskusi dan LKS siswa mampu } \\
\text { menentukan rumus untuk mencari Luas } \\
\text { Permukaan dan Volume bangun ruang. } \\
\text { Kemudian dengan konsep pengaitan antara } \\
\text { definisi Kubus, Balok, Prisma dan Limas } \\
\text { siswa juga mampu membuktikan rumus } \\
\text { untuk mencari Luas Permukaan dan Volume }\end{array}$ \\
\hline $\begin{array}{l}\text { Melakukan permainan LBC dan } \\
\text { menyelesaikan masalah yang } \\
\text { disajikan untuk melatih } \\
\text { kreativitas dalam memecahkan } \\
\text { masalah. }\end{array}$ & $\begin{array}{l}\text { Melalui kolaborasi dan diskusi ahli, siswa } \\
\text { memainkan permainan LBC yang akan } \\
\text { dimainkan menggunakan perangkat keras } \\
\text { Laptop yang dimiliki siswa. Dalam satu } \\
\text { kelompok siswa hanya perlu menyediakan } \\
\text { satu laptop untuk dimainkan. }\end{array}$ \\
\hline
\end{tabular}

d. Analisis Konsep

Hasil dari analisis konsep yang dilakukan berdasarkan buku pegangan siswa dan Kurikulum KTSP materi pokok Bangun Ruang Sisi Datar adalah supaya siswa dapat membentuk peta konsep anatar definisi prisma, balok, kubus dan limas.

e. Spesifikasi Tujuan Pembelajaran

Setelah mengikuti serangkaian kegiatan pembelajaran menggunakan model pembelajaran Jigsaw dengan permainan LBC, peserta didik secara individu dapat:

1) memahami sifat-sifat prisma, balok, kubus, limas dan mampu mendefinisikan prisma , balok, kubus, limas.

2) menentukan jaring-jaring prisma, balok, kubus, limas dengan berbagai macam bentuk.

3) menentukan luas permukaan dan volume prisma, balok, kubus, limas.

4) memecahkan masalah yang berkaitan dengan bangun ruang dengan kreativitas yang dimiliki.

2. Tahap Perancangan (Design)

Pada tahap perancangan, hal yang dirancang sebagai berikut:

a. Perancangan Komponen-Komponen Model Pembelajaran.

Perancangan komponen-komponen model pembelajaran berupa pemilihan teori pembelajaran yang mendukung pengembangan model pembelajaran Jigsaw dengan permainan LBC. Diperoleh sintaks model pembelajaran sebagai berikut.

1) Persiapan 
Pada langkah ini dibentuk tim Jigsaw yang nantinya dibagi menjadi ahli kubus, balok, prisma dan limas.

2) Diskusi kelompok ahli

Tiap ahli dari kelompok jigsaw berdiskusi materi ahli.

3) Diskusi kelompok Jigsaw

Ahli kembali ke kelompok Jigsaw kemudian menyampaikan materi yang telah didiskusikan dalam kelompok ahli. Di setiap akhir diskusi diberikan tugas individu.

4) Permainan LBC

Permainan LBC dilakukan dalam kelompok Jigsaw.

5) Penghargaan TIM

Kelompok Jigsaw dengan skor perolehan tertinggi diberikan penghargaan secara kelompok dan secara individu siswa dengan skor tertinggi juga mendapatkan penghargaan.

b. Perancangan Perangkat Model Pembelajaran.

Yang meliputi perancangan RPP, LKS dan permainan LBC serta merancang instrumen yang diperlukan untuk mendapatkan data yang dibutuhkan. Tahapan perancangan perangkat meliputi perancangan garis besar isi perangkat pembelajaran, penulisan naskah, pelaksanaan produksi.

c. Penyusunan Instrumen Penilaian Kevalidan,Kepraktisan dan Keefektifan.

Pada tahap ini dirancang instrumen lembar validasi model, lembar penilaian kepraktisan, lembar penilaian keterlaksanaan oleh observer, angket respon guru, angket respon siswa, dan tes pemecahan masalah yang kemudian divalidasi terlebih dahulu oleh ahli Instrumen. Pada tahap ini dilakukan pula uji coba tes pemecahan masalah yang akan digunakan untuk mengukur kreativitas siswa dalam memecahkan masalah matematika yang sebelumnya diujicobakan terlebih dahulu ke siswa kelas VIII SMP N 1 Sukoharjo.

3. Tahap Pengembangan (Develop)

Tahap pengembangan meliputi tahap validasi oleh ahli materi beserta ahli pembelajaan dan ahli media, dan ujicoba lapangan untuk menilai kepraktisan dan efektivitas model.

a. Validasi Ahli

Hasil lembar validasi oleh ketiga ahli terangkum dalam Tabel 4. 
Tabel 4. Skor validasi model pembelajaran Jigsaw dengan permainan LBC

\begin{tabular}{llll}
\hline \multirow{2}{*}{ Validator } & \multicolumn{2}{c}{ Ahli Materi beserta Ahli Pembelajaran } & Ahli Media \\
\cline { 2 - 4 } & Dr. Budi Usodo,M.Pd & Dr. Sumardi,M.Si & Dwi Maryono,M.Kom \\
\hline Kror & $3,37(84,2 \%)$ & $3,74(93,5 \%)$ & $3,53(88,3 \%)$ \\
Kesimpulan & Baik & Sangat Baik & Sangat Baik \\
& Valid digunakan di & Valid digunakan & Valid digunakan di \\
& lapangan dengan revisi & dilapangan tanpa & lapangan dengan revisi \\
& kecil. & revisi. & kecil. \\
\hline
\end{tabular}

Berdasarkan rerata skor kevalidan yang diperoleh dari ketiga ahli sebesar 3,55 model Jigsaw dengan permainan LBC dinyatakan termasuk dalam kriteria sangat baik atau $88,67 \%$ validator menyatakan model Jigsaw dengan permainan baik.

b. Uji Coba Lapangan.

Setelah model pembelajaran Jigsaw dengan permainan LBC dikatakan valid baik dengan revisi atau tanpa revisi, pengumpulan data dilanjutkan untuk memperoleh data mengenai kepraktisan dan efektivitas model pembelajaran Jigsaw dengan permainan LBC.

1) Kepraktisan model pembelajaran Jigsaw dengan permainan LBC.

Teknik yang digunakan untuk memperoleh skor penilaian keterlaksanaan model pembelajaran adalah dengan cara memberikan angket penilaian keterlaksanaan model. Hasil penilaian terangkum pada Tabel 5.

Tabel 5. Skor Penilaian Keterlaksanaan Model Jigsaw dengan permainan LBC (menilai kepraktisan).

\begin{tabular}{lll}
\hline Penilai & Estik Subawanti,S.Pd & Rini Kurniasih,S.Pd \\
\hline Rerata Skor & $3,72(93 \%)$ & $3,16(79,2 \%)$ \\
Kriteria & Sangat Baik & Baik
\end{tabular}

Dari lembar penilaian keterlaksanaan model pembelajaran Jigsaw dengan permainan LBC diperoleh rerata skor 3,44 model dinyatakan dalam kriteria sangat baik atau $86,1 \%$ penilai menyatakan model baik untuk diterapkan di kelas dan guru matematika pada kelas eksperimen menyatakan bahwa model dapat diterapkan dalam kelas.

2) Keefektifan model pembelajaran Jigsaw dengan permainan LBC

Dari hasil obsrvasi kegiatan pembelajaran menggunakan model pembelajaran Jigsaw dengan permainan LBC oleh kedua observer, keterlaksanaan pembelajaran menggunakan model Jigsaw dengan permainan LBC sebesar 3,1375. Tingkat reliabilitas instrumen lembar obsrvasi kegiatan pembelajaran menggunakan model Jigsaw dengan permainan LBC sebesar $87,83 \%$, sehingga instrumen termasuk dalam kategori baik. Dari hasil angket respon siswa terhadap model Jigsaw dengan permainan LBC, respon siswa 
terhadap model adalah cukup baik dengan rerata skor keseluruhan sebesar 2,793. Kemudian untuk respon guru mengenai model Jigsaw dengan permainan LBC guru menyatakan bahwa anak menjadi lebih aktif, semua siswa terlibat dalam proses belajar tetapi terdapat beberapa masukan bahwa untuk siswa yang kurang aktif dalam proses pengkonstruksian pengetahuan sulit maka perlu di perhatikan secara khusus. Kemudian guru juga menyatakan bahwa tertarik mnerapkan model Jigsaw dengan permainan LBC untuk kelas tertentu. Kemudian dalam hal skor kreativitas dalam memecahkan masalah matematika yang diberikan siswa yang dikenai model pembelajaran Jigsaw dengan permainan LBC lebih baik daripada model pembelajaran Jisaw. Jadi, dapat dikatakan model Jigsaw dengan permainan LBC yang dikembangkan efektif untuk digunakan dalam pembelajaran.

4. Tahap Penyebaran (Disseminate)

Tahap penyebaran (disseminate) meliputi pengemasan dan distribusi terbatas. Saran perbaikan yang direkomendasikan pada saat uji coba lapanan diterapkan pada fase pengemasan ini, sehingga diharapkan dapat memaksimalkan model Jigsaw dengan permainan LBC yang nantinya akan diterapkan oleh guru di sekolah sasaran pendistribusian terbatas dari model Jigsaw dengan permainan LBC.

\section{SIMPULAN DAN SARAN}

Hasil penelitian pengembangan ini berupa model pembelajaran Jigsaw dengan permainan LBC yang diterapkan pada materi bangun ruang sisi datar kelas VIII SMP yang: (1) Valid dengan rerata skor kevalidan sebesar 3,55 sehingga termasuk dalam kriteria sangat baik. (2) Praktis dengan rerata skor keterlaksanaan model Jigsaw dengan permainan LBC oleh penilai (sebelum diterapkan) sebesar 3,44 sehingga termasuk dalam kriteria sangat baik dan guru menyatakan bahwa model Jigsaw dengan permainan LBC dapat diterapkan di kelas. (3) Efektif untuk diterapkan di kelas dngan kriteria keefektifan model didasarkan pada kreativitas dalam memecahkan masalah matematika yang diberikan model pembelajaran Jigsaw dengan permainan LBC lebih baik dibanding model pembelajaran Jigsaw, penilaian oleh observer saat pembelajaran menggunakan model Jigsaw dengan permainan LBC sebesar 3,1375 dalam kriteria baik dengan reliabilitas 87,83\%,. Respon siswa terhadap model adalah cukup dengan rerata skor keseluruhan sebesar 2,793 sehingga termasuk dalam kategori cukup baik. Serta guru memberikan pernyataan - pernyataan positif bahwa model Jigsaw dengan permainan LBC baik, anak-anak menjadi lebih aktif dan permainan LBC menarik semua siswa. 
Berdasarkan hasil pembahasan, dapat disimpulkan bahwa model pembelajaran Jigsaw dengan permainan LBC memenuhi kriteria kevalidan, kepraktisan dan keefektifan.

Berdasarkan kesimpulan dari hasil penelitian dan pembahasan model Jigsaw dengan permainan LBC dinyatakan valid, praktis dan efektif. Oleh karena itu dalam pengaplikasian produk perlu dilakukan penerapan lebih lanjut oleh guru matematika di kelas.

\section{DAFTAR PUSTAKA}

Baghetto, R. A. 2010. Creativity in the Classroom. In Kaufman, James $C$ \& Sternberg, Robert $J(E d s)$. The Cambridge Handbook of Creativity. Cambridge University Press.

Carpenter, J.M. 2006. Effective Teaching Method for Large Classes.Journal Family and Consumer Sciences Education,Vol. 24, No. 2, Fall/Winter,hlm.13 - 23.

Fasko, D. 2000. Education and Creativity. Creativity Research Journal. Vol. 13, No. 3 \& 4, pp.317-327

Haylock, D. 1997.Recognizing Mathematical Creativity in Schoolchildren. ZM Volume 29 (June 1997) Number 3. Electronic Edition ISSN 1615-679X. pp 68-74.

Meletiou,M. 2012. Game-Enhanced Mathematics Learning For Pre-Service Primary School Teachers.ICICTE 2012 Proceedings.pp.455 - 465.

Murniati, E. 2012. Pendidikan \& Bimbingan Anak Kreatif.Yogyakarta:Pedagogia.

Nieveen, N.2000. Prototyping to Reach Product Quality.In J. Vam den Akker, R Branch,K Gustafson, N Nieveen and Tj. Plomp(Eds). Desigh and Development Methodology in Education (hlm 125-136) Dodrecht: Kluwer Academic Publisher

Perkin, D.V. and Saris, R.N. 2001.A jigsaw Classroom, technique for undergraduate Statistics Course. Teaching of Psychology. Vol. 28, Page 111-113. Diakses 11 Sepetember 2014

Rockler, M.J. 1998. Innovative Teaching Strategies.Arizona:Gorsuch Scarisbrick.

Santrock, J.W. 2007. Perkembangan Anak.Jakarta:Erlangga.

Siswono,T.Y.E. 2010.Leveling Students' Creative Thinking In Solving and Posing Mathematical Problem. IndoMS.J.M.E. Vol.1 No. 1 Page 17 - 40. Diakses pada 13 September 2014

Siswono,T.Y.E. 2013. Pembelajaran Matematika yang Menumbuhkan Tindak Pikir Kreatif.Jurnal FMIPA UNESA.

Thiagarajan,S.,Semmel,D..\& Semmel,M.. 1974. Instructional evelopment for Training Teachers of Exceptional Children. Minnesota: Indiana University.

Widoyoko, E.P. 2009. Evaluasi Program Pembelajaran.Yogyakarta:Pustaka Pelajar 